\title{
How Often Have You Felt Disadvantaged? Explaining Perceived Discrimination
}

\author{
Claudia Diehl · Elisabeth Liebau · Peter Mühlau
}

Received: 16 October 2020 / Accepted: 7 March 2021 / Published online: 4 May 2021

(C) The Author(s) 2021

\begin{abstract}
Based on longitudinal data from Germany, we analyze how perceptions of discrimination change once migrants' integration evolves. Individuals who identify more strongly with the host country, speak the language, have native friends, and are adequately employed report less discrimination overall. However, groupspecific analyses reveal that German-born Turks feel more rather than less discriminated against after their language skills and their identification increase. For this group, we find evidence for the "integration paradox", i.e., the finding that better educated migrants have more rather than less negative attitudes about the host society. Results suggest that attributional processes rather than rising exposure to discrimination might be the main mechanism linking integration to higher levels of perceived discrimination. Obviously, discrimination does not disappear for groups facing salient ethnic boundaries and is met with growing awareness and sensitivity among individuals that have become more similar to the majority of members. This, in turn, by no means implies that perceived discrimination is detached from reality.
\end{abstract}

Online Appendix: www.kzfss.uni-koeln.de/sites/kzfss/pdf/Diehl-et-al.pdf

\author{
C. Diehl $(\bowtie)$ \\ Universität Konstanz \\ Universitätsstraße 10, 78467 Konstanz, Germany \\ E-Mail: claudia.diehl@uni-konstanz.de \\ E. Liebau \\ Deutsches Institut für Wirtschaftsforschung e.V. (DIW Berlin) \\ Mohrenstraße 58, 10117 Berlin, Germany \\ E-Mail: eliebau@diw.de \\ P. Mühlau \\ Department of Sociology, Trinity College Dublin \\ 3 College Green, Trinity College, Dublin 2, Ireland \\ E-Mail: MUHLAUP@tcd.ie
}


Keywords Germany · Discrimination · Integration · Immigration · Ethnic boundaries

\section{Wie häufig wurden Sie benachteiligt? Zur Erklärung von Diskriminierungswahrnehmungen}

Zusammenfassung Im Rahmen einer Längsschnittanalyse des sozio-oekonomischen Panels gehen wir der Frage nach, wie sich Diskriminierungswahrnehmungen von Einwanderern und ihren Nachkommen im Laufe des Integrationsprozesses verändern. Insgesamt betrachtet fühlen sich Migrantinnen und Migranten, deren Integration weiter fortgeschritten ist, seltener aufgrund ihrer Herkunft benachteiligt. Allerdings zeigen gruppenspezifische Analysen, dass in Deutschland geborene Türkeistämmige sich mit zunehmenden deutschen Sprachkenntnissen und zunehmender Identifikation mit Deutschland stärker diskriminiert fühlen. Für diese Gruppe finden wir Hinweise auf ein Integrationsparadox, das heißt für die These, dass gerade besonders weitgehend integrierte Migrantinnen und Migranten negativere Einstellungen zum Zielland aufweisen. Unsere Befunde sprechen dafür, dass diesem Sachverhalt vor allem attributionale Prozesse zugrunde liegen und dagegen, dass Individuen, deren Integration weiter fortgeschritten ist, Diskriminierungsprozessen besonders stark ausgesetzt sind. Gerade wenn diese Herkunftsgruppen angehören, die mit salienten ,ethnic boundaries“ konfrontiert sind, verschwindet Diskriminierung mit zunehmender Integration nicht - und trifft gleichzeitig bei den Betroffenen auf ein wachsendes Bewusstsein für Diskriminierung und eine größere Sensitivität gegenüber dieser. Dies bedeutet im Umkehrschluss nicht, dass wahrgenommene Diskriminierung losgelöst von der Realität wäre.

Schlüsselwörter Deutschland · Diskriminierung · Integration · Einwanderung · Ethnische Grenzziehungen

There are times when people do not know, but still wonder, whether they have been treated poorly because of the color of their skin. This possibility [...] can cause a kind of rumination whose emotional strain can be taxing (Small and Pager 2020, p. 63).

\section{Introduction}

Analyzing the impact of perceived discrimination (PD) on integration outcomes is an increasingly popular method of linking discrimination and integration. Survey questions on migrants' perceptions of discrimination are included in most surveys that are tailored to immigrants and their descendants. These self-reports of discrimination are then included as explanatory variables in statistical models. They serve as a proxy for experiences of discrimination, allowing researchers to analyze how these affect integration outcomes such as making friends with natives (Schacht et al. 2014), patterns of identification (de Vroome et al. 2014; Diehl et al. 2016; Jasin- 
skaja-Lahti et al. 2009; Martinovic and Verkuyten 2012; Skrobanek 2009; Verkuyten and Yildiz 2007; Jugert et al. 2020), levels of acculturation (Fleischmann and Phalet 2012; Maliepaard and Alba 2016; Voas and Fleischmann 2012; Röder and Lubbers 2016), intentions to return to the country of origin (Saint Pierre et al. 2015), political engagement in the host country (Fischer-Neumann 2014; Fleischmann et al. 2011), trust in mainstream institutions (Röder and Mühlau 2012), and integration in the educational system (Berkel et al. 2010) or on the labor market (Koopmans 2016).

Although these studies rarely ask what these perceptions actually capture, several articles have recently been published that explore the concept of perceived discrimination itself. Most start out from the so-called "integration paradox" (ten Teije et al. 2013; van Doorn et al. 2013), i.e., the fact that better educated migrants have more negative attitudes about the host society, and report more discrimination (Flippen and Parrado 2015; Maxwell 2015; Tuppat and Gerhards 2021; Schaeffer 2019; Steinmann 2019; Flores 2015; McGinnity and Gijsberts 2016). This finding is at odds with assimilation theory, which predicts that discrimination decreases when migrants become more similar to majority members (Gordon 1964, p. $70 \mathrm{ff}$.) and raises the question of what PD actually captures. Do more integrated migrants actually experience more discrimination, or are they more likely to attribute negative experiences to discrimination? In this article, we aim to build upon and move beyond the existing studies on the concept of PD by conducting a comprehensive and longitudinal analysis of the link between integration and PD based on panel data from Germany. We argue that analyzing how PD changes as integration in different spheres evolves provides new insight into the question of what PD actually captures.

Substantively - and in line with assimilation theory-our results speak against the possibility that more integrated migrants experience more discrimination. They rather suggest that more integrated migrants who belong to groups that face salient ethnic boundaries are more likely to attribute ambiguous situations to discrimination. In this respect, our findings are in line with the few studies that point toward a groupspecific relationship between integration and perceptions of discrimination (e.g., Flores 2015; Steinmann 2019). We discuss the implications of this result for future analyses of the link between discrimination and integration. We conclude by pointing out that questioning the suitability of PD as an indicator for actual discrimination by no means implies that we question the reality of discrimination itself.

\section{Explaining Perceived Discrimination: Existing Findings and Open Questions}

Earlier studies on the "integration paradox" describe how migrants grow more emotionally distant from their host societies as their integration proceeds (ten Teije et al. 2013; Verkuyten 2016). Despite its broader original meaning (Tolsma et al. 2012), more recent texts have focused on the phenomenon that migrants who are better integrated report more rather than fewer experiences of discrimination (Flippen and Parrado 2015; Maxwell 2015; Tuppat and Gerhards 2021; Schaeffer 2019; Steinmann 2019), especially when they belong to origin groups that are visibly distinct from the majority population (Flores 2015). 
In their attempts to explain why integration and PD do not necessarily seem to follow the predicted dynamics, all studies emphasize that PD is not only a reflection of exposure to actual discrimination but also a way of seeing and interpreting the world, in other words, the result of attributional processes (Diehl and Liebau 2017). The most recent studies in particular have analytically disentangled these two mechanisms in greater detail and analyzed which of the two is underlying the positive link between integration processes and PD (for a succinct summary see Schaeffer 2019).

As outlined in these accounts, the concept of exposure is rather straightforward. More integrated migrants who live in desegregated neighborhoods with many majority members and have left the ethnic niches of the labor market are at a higher risk of experiencing discrimination because they have more contact with potential discriminators. Steinmann (2019) analyses PD among migrants from Poland and Turkey in Germany and shows that those who spent a lot of time in contexts where they had opportunities to meet Germans reported substantially more discrimination (although other factors also played a role in shaping perceptions of discrimination). However, his study is correlational and limited to two groups of recent migrants, so it is not clear whether these findings can be generalized to the broader immigrant population.

In a similar vein, Tuppat and Gerhards (2021) analyze data from Germany that includes information on respondents' first names. They show that the positive link between education and PD holds for migrants with non-German first names, whereas those with German first names are essentially "invisible" and should thus not be exposed to discrimination: "This indicates that exposure due to different opportunity structures plays a central role in explaining the discrimination paradox" (Tuppat and Gerhards 2021, p. 10). However, as they do not analyze migrants' perceptions of discrimination along with their frequency of contacts with natives, the evidence for the exposure mechanism remains rather indirect.

The second factor obviously affecting PD, attributional processes, is theoretically more complex. The studies mentioned above have subsumed different mechanisms under this term. A first mechanism is cognitive in nature and emphasizes that migrants who know the language and have higher levels of education are better able to detect discrimination than migrants who barely understand their surroundings (Saint Pierre et al. 2015, p. 1842). In other words, they are more sensitive to and aware of discrimination: “... higher educated immigrants [...] are more aware of the negative climate that immigrants are confronted with ..." (Steinmann 2019, p. 1381).

A second mechanism is aspirational in nature. The proponents of the "integration paradox" (ten Teije et al. 2013; Verkuyten 2016) argue that highly educated immigrants have stronger demands for equal treatment, comparing themselves with the majority members rather than with other-often disadvantaged-immigrants, and they feel more deprived if this is denied to them.

A third mechanism is motivational and argues that attributing a negative event or encounter to discrimination can be a coping strategy that reflects the need to deal with situations in a way that is nonthreatening to an individual's self-esteem. It thus says little about whether or not discrimination actually occurred (Branscombe et al. 1999, p. 136; see also Major and O'Brien 2005, p. 404; Crocker and Major 
1989). Empirical support for this is provided by Thijs and Piscoi (2016, p. 170), who show "that it can be self-protective to make attributions to discrimination" among children who experience social exclusion and bullying (for a qualification of the "discounting hypothesis" see Schmitt and Branscombe 2002). Schaeffer (2019) relates this mechanism to the integration paradox by showing that status aspirations and educational success—or the lack thereof-interact in shaping PD.

Although all these studies provide important insights into the question of whether exposure or attributional processes (or both) contribute to migrants' perceptions of discrimination, they all concede that it is difficult to ultimately disentangle these two aspects using survey data. This would require controlling for exposure and analyzing the variation in attributional processes (for a different methodological approach based on a factorial survey, see Maxwell 2015).

We start out from this challenge and provide further insight into the relative importance of exposure and attribution in explaining the integration paradox. We do so, first, by analyzing panel data over a time span of about 20 years. Almost all existing studies are based on cross-sectional data, which raises questions of causality (with the exception of Flores 2015). In our longitudinal study, we can not only see if better integrated migrants perceive more discrimination, but we can also analyze if and how PD changes as integration processes evolve.

Second, we analyze the link between integration in different domains and PD in a more comprehensive way than previous studies, which have mostly focused on education and, in addition, on several individual aspects of the integration process such as language skills or migrants' social context or ties. But these different dimensions, e.g., identifying with the host country, speaking its language, and having friends from the majority population, are empirically highly correlated. Therefore, focusing only on specific aspects of the integration process and leaving others out may obscure how different dimensions of integration are related to PD. After all, integration in some dimensions has repercussions for migrants' exposure to potential discriminators, whereas integration in other areas affects their awareness of unequal treatment or their aspirations to be treated the same way as members of the majority population. An encompassing and domain-specific analysis of this relationship may thus provide further insight into the mechanisms linking integration to PD.

\section{Explaining Perceived Discrimination: The Role of Integration and Psychological Characteristics}

In the following, we develop the theoretical framework for our empirical analyses by spelling out in greater detail how integration in different domains affects PD according to previous studies. Doing so, we differentiate between an individual's exposure to discrimination and the attributional processes behind PD, and also discuss group-specific variation in this link (Sect. 3.1). We further explain what we can learn from studying how psychological characteristics affect PD (Sect. 3.2). 


\subsection{Integration and PD: Exposure and Attribution}

The "integration paradox" focuses on the phenomenon that minority members with higher levels of education are often more emotionally distant to the host society and also feel more discriminated against than less educated migrants. As in other fields, for example, xenophobia or ethnic exclusionism (Hello et al. 2002; Coenders and Scheepers 2003), the mechanisms at work behind this "catch all" variable-education-are complex. This is because higher levels of education often come along with higher levels of integration in other domains, e.g., more ties with natives, better language skills, rising levels of national identification and more adequate jobs.

Migrants' social integration, often measured as their contacts with members of the majority population (and thus with potential discriminators) should mostly affect migrants' exposure to discrimination. It has been argued that more contact with potential discriminators increases the possibility of being discriminated against (Steinmann 2019). This assumption is, however, at odds with the prediction of contact theory, which assumes that increasing voluntary contacts would reduce discrimination (ten Teije et al. 2013, p. 279). Furthermore, more integrated individuals usually have more contact with better educated natives (due to homophily) who are substantively less prejudiced overall (Coender and Scheepers 2003; Hello et al. 2002). Although it is clear that migrants' social integration should above all affect their exposure to discrimination, the direction of the link between contacts and PD is thus unclear.

Migrants' acculturation, namely improving language skills, should clearly reduce their exposure to discrimination as it renders an individual's ethnic background less obvious and thus less salient. For many members of the majority population, language skills are also one of the most important criteria for belonging (Pew Research Center 2017) and should thus be accompanied by greater acceptance and less discrimination (for empirical evidence see Schmaus 2019; Horr et al. 2018). The available studies suggest, however, that the relationship between acculturation and the exposure to discrimination varies between ethnic origin groups (Flores 2015; Steinmann 2019). Acculturation might reduce the exposure to discrimination for groups facing less salient, or "blurred" (Alba 2005) ethnic boundaries (e.g., Western Europeans), which become increasingly transparent as they acculturate ${ }^{1}$. But this may be less applicable to visible and unpopular immigrant groups facing "bright" ethnic or racial boundaries (Wimmer 2008). For these groups, their exposure to discrimination should remain, even as their integration proceeds-no matter how similar they become to the majority. Flores (2015) presents empirical evidence for Spain, supporting his argument that the effect of acculturation on PD depends on

\footnotetext{
1 The link between a group's visibility and the salience of ethnic boundaries is complex and has not been spelled out by Flores (2015), who emphasized the importance of visibility and authors such as Steinmann, who emphasize the salience of boundaries (2019). Strictly speaking, one could argue that neither visibility without salient boundaries, e.g., skin color in a society without a salient racial divide, nor salient boundaries without visibility, e.g., Muslim converts who do not follow a religious dress code, experience ongoing discrimination when their integration proceeds. But these examples show that, empirically, visibility and salient ethnic boundaries co-exist.
} 
a migrant group's distinctiveness: “...generally speaking, as acculturation increases, immigrants will report less cultural discrimination. Nevertheless, as immigrants acculturate, those who are visibly distinct will increasingly report racial discrimination" (Flores 2015, p. 263). In his study, these groups may include migrants from Africa but also those who are in a "middle category" in terms of their phenotypical distinctiveness, like many Muslims. Although it is plausible that improving language skills may reduce some migrants' exposure to discrimination, it is highly implausible to assume that they increase exposure. However, acculturation processes may increase migrants' awareness of discrimination. Once migrants can follow the often migration-skeptical debate in the media and understand derogatory comments, they are more apt to detect discrimination (Steinmann 2019). In other words, although exposure to discrimination should decline for some migrant groups as their language skills improve, they could become more aware of the discrimination around them.

Rising levels of identification with the host society are inherently "invisible" to outside observers and should thus leave exposure to discrimination unaffected. However, those who consider themselves to be members of the majority population may have high aspirations for equal treatment-and be particularly disturbed if it they feel it is denied to them (see Schaeffer 2019). But although rising expectations for equal treatment could lead to an increase in PD, another mechanism may play a role as well and work in the opposite direction. Identifying as a member of the majority population may lower the salience of an in group-out group distinction. Alba and Nee's definition of assimilation as an "attenuation of an ethnic and racial distinction and the cultural and social differences associated with it" (Alba and Nee 1997, p. 834) may also affect the perceptions of discrimination. Migrants who identify strongly as German may thus perceive misfortune or unfriendly treatment less often through an "ethnic lens" and therefore ultimately perceive less discrimination.

Even if one takes into account that rising levels of education are often confounded with more native friends, a higher proficiency in the host country's language, and higher levels of identification, migrants' structural integration in the educational system and on the labor market itself may affect their PD as well. On the one hand, education may affect exposure to discrimination, although the direction of this link is again far from obvious: in many ethnically stratified immigration countries, migrants become more similar to members of the majority population as their level of education increases. According to the principles of homophily, this should turn migrants into more desirable interaction partners and lead to declining levels of discrimination (ten Teije et al. 2013, p. 279). However, other authors have argued that migrants may be increasingly perceived as competitors when they have achieved higher levels of education and left the ethnic niches of the labor market (Flippen and Parrado 2015).

On the other hand, Schaeffer (2019) takes up arguments from social psychology and concludes that higher levels of education may reduce migrants' need for selfesteem-protecting explanations for a lack of school success. Attributing the latter to discrimination is one such strategy. Based on survey data from the EURISLAM project he argues that immigrant children who have not matched their parents' high educational level or met their aspirations have probably been exposed to discrimination-otherwise they would not have failed-but also "have cause to frame their 
experiences in terms of discrimination as an ex-post rationalization of their lack of success" (Schaeffer 2019, p. 67).

The discussion has so far shown that integration may affect PD in complex ways. For all of the possible relationships outlined so far, theoretical mechanisms have been specified. We do not start out our empirical analysis by "taking sides" or focusing on one specific mechanism, nor do we introduce a new one. We rather try to provide-necessarily indirect-evidence on which mechanisms are more important in linking integration to PD by exploring how different domains of integration are empirically related to PD. We do so by studying this relationship from a comprehensive and longitudinal perspective. If we find, for example, that rising levels of (invisible) identification lead to higher levels of PD, it is unlikely that exposure to discrimination plays an important role. If, in turn, social integration leads to higher levels of PD, this would strengthen the argument that more contact with potential discriminators is the decisive mechanism.

We expect the mechanisms linking integration and PD to hold for both native and foreign-born individuals. However, generational differences may already tell us something about exposure versus attribution. Exposure should be lower for secondgeneration migrants for less visible origin groups but remain at similar levels (but not increase) for more visible groups. Migrants' awareness of unequal treatment and their aspirations for equal treatment should, however, be higher among those individuals who were born in the host society.

Another group of factors that we argue is helpful in disentangling the exposure attribution puzzle are the psychological characteristics of those who feel discriminated against.

\subsection{Psychological Characteristics}

None of the studies discussed above have considered psychological characteristics, such as locus of control or personality traits (e.g., agreeableness and extraversion). However, doing so may provide further insight into the relative importance of exposure and attribution in explaining PD. So far, these factors have received far more interest in (social) psychology than in sociology. Studies suggest that personality traits might in fact be systematically related to PD (Sutin et al. 2016; for an older review, see Phinney et al. 1998). This finding supports the argument that PD reflects attributional processes rather than exposure to discrimination. After all, attribution is a psychological mechanism and thus likely to be affected by psychological characteristics. The few studies that look into this relationship provide empirical support for this: "[...] participants who scored higher in neuroticism and lower in conscientiousness were more likely to report at follow-up that they experienced discrimination" (Sutin et al. 2016, p. 162). In other words, some individuals seem to be more prone to attributing unpleasant encounters or experiences to prejudice and discrimination than others. It would lend support to the argument that PD reflects, to some extent, attributional processes if it is systematically affected by relatively stable psychological characteristics. For example, it is highly plausible that individuals with an "external locus of control" are more likely to attribute negative events to discrimination: "[...] responsibility for success or failure is attributed to the actor 
Table 1 Mechanisms linking integration and exposure to discrimination/attributional processes behind perceived discrimination (PD)

\begin{tabular}{|c|c|c|c|c|}
\hline $\begin{array}{l}\text { Domain of integra- } \\
\text { tion }\end{array}$ & Exposure & $\begin{array}{l}\text { Impact } \\
\text { on PD }\end{array}$ & Attribution & $\begin{array}{l}\text { Impact } \\
\text { on PD }\end{array}$ \\
\hline Social integration & $\begin{array}{l}\text { Increasing contact } \\
\text { with potential dis- } \\
\text { criminators }\end{array}$ & + & No effect & 0 \\
\hline \multirow[t]{2}{*}{$\begin{array}{l}\text { Identificational } \\
\text { integration }\end{array}$} & \multirow[t]{2}{*}{ No effect } & \multirow[t]{2}{*}{0} & $\begin{array}{l}\text { Higher aspirations for equal } \\
\text { treatment }\end{array}$ & + \\
\hline & & & $\begin{array}{l}\text { Lower salience of ethnic bound- } \\
\text { ary and tendency to frame expe- } \\
\text { riences through "ethnic lens" }\end{array}$ & - \\
\hline Acculturation & $\begin{array}{l}\text { Reduced visibility } \\
\text { (not for "visible" } \\
\text { minorities) }\end{array}$ & - & $\begin{array}{l}\text { Greater awareness of discrimina- } \\
\text { tion } \\
\text { (especially for visible minorities) }\end{array}$ & + \\
\hline \multirow{2}{*}{$\begin{array}{l}\text { Structural } \\
\text { integration (labor } \\
\text { market, education } \\
\text { system) }\end{array}$} & $\begin{array}{l}\text { Greater similarity, } \\
\text { homophily }\end{array}$ & - & $\begin{array}{l}\text { Declining need to "rationalize" } \\
\text { misfortune }\end{array}$ & - \\
\hline & Greater competition & + & & \\
\hline $\begin{array}{l}\text { Psychological } \\
\text { characteristics }\end{array}$ & No effect & 0 & $\begin{array}{l}\text { E.g., locus of control: effect } \\
\text { on likelihood that misfortune } \\
\text { is attributed externally, i.e., to } \\
\text { discrimination }\end{array}$ & + \\
\hline
\end{tabular}

a Direction of effect depends on specific characteristics, e.g., low affective well-being: more negative way of framing negative experiences

when perceived as caused by internal factors (ability or effort), but less so when perceived to be due to external factors [...]" (Ajzen 2002, p. 675). At the same time, it is unlikely that psychological characteristics, such as external locus of control, affect exposure to discrimination-although it is theoretically possible that certain personality types self-select into discriminatory situations (see Sutin et al. 2016).

In Table 1 we sum up the possible mechanisms outlined in previous studies, specifying how integration in different domains and psychological characteristics affect either exposure to discrimination or the attributional processes behind PD.

\section{Data, Indicators, and Analytic Strategy}

An empirical test of these assumptions comes along with substantial data requirements. Only by using panel data is it possible to analyze whether PD changes as integration proceeds and whether integration is negatively affected by PD. In addition, these analyses need to be done separately for groups that differ with respect to their visibility and the nature of the ethnic boundaries that they face. Further data requirements include suitable indicators for $\mathrm{PD}$, for different dimensions of integration-including language skills, social contacts with natives and identification with the host society-and for psychological characteristics. 


\subsection{Data and Indicators: The German Socio-Economic Panel}

The German Socio-Economic Panel study is one of the few available data sets that render it possible to study the link between integration and PD from a longitudinal perspective $\left(\mathrm{SOEP}^{2}\right)$. The SOEP has been used in numerous studies on immigrant integration. Labor migrants were oversampled when the original sample was taken in 1984 and several refresher samples have been added over the years to account for the increasing diversification of the immigrant population. As of 2015, four immigrant samples have been drawn (most importantly in 1994, 2013, and 2015; for an overview, see Liebau and Tucci 2015; Brücker et al. 2014). The same households are encouraged to stay in the panel for as long as possible-including individuals who join these households as, for example, children or spouses (Goebel et al. 2019). The SOEP questionnaire includes a broad set of migrant-specific and integrationrelated variables in addition to questions asked to all respondents. Since our variable of interest, PD, has been measured in the SOEP since 1996, we use all the survey waves from 1996 to 2015 (SOEP v.32.1; for information on the generation of variables and missing values see Table A1 in the Online Appendix). A measure of PD is available annually in the SOEP from 1996 on (though only bi-annually starting from 2011) via the question: How often have you felt disadvantaged in the last two years because of your ethnic origin? The answer categories are: often, seldom, or never. This captures the personal perceptions of what Quillian (2006) has described as "the difference between the treatment that a target group actually receives and the treatment they would receive if they were not members of the target group but were otherwise the same" (Quillian 2006, p. 302; see also National Research Council 2004, p. 56ff.; Pager 2007). In the absence of a more direct indicator for discrimination, we-like other recent studies on perceived discrimination (Schaeffer 2019; Tuppat and Gerhards 2020) —use this indicator even though strictly speaking, one could argue that it also captures disadvantage that has nothing to do with discrimination, e.g., disadvantage because of parents' low levels of education as labor migrants. In addition, one should keep in mind that this indicator is different from "group discrimination," that is, perceptions that the ethnic or cultural group to which an individual belongs is being treated unfairly, a measure not available in the SOEP (ten Teije et al. 2013, p. 280). Only a few individuals say that they have experienced discrimination "often" (e.g., only $8 \%$ of respondents in 2000). We therefore collapse the categories "seldom" and "often" in our analyses.

Besides the level of education, which is key for assessing the "integration paradox" but is not necessarily an indicator for integration itself (as many migrants completed their education before migrating), the SOEP reports measures of integration in different domains in a detailed way: integration into the status systems of the host country (being employed and holding a job that is adequate to a respondent's

\footnotetext{
2 www.diw.de/de/soep.
} 
educational endowments ${ }^{3}$ ), social integration (the share of Germans among friends), identification with the host country (feeling German), and speaking the majority language (self-assessed German language skills).

Psychological characteristics are included in the SOEP as well, although most of them have only been measured a few times-and only in recent SOEP waves, as they are considered to be invariant over time.

Case numbers are large enough in the SOEP to conduct group-specific analyses, at least for the large ethnic groups. We differentiate between Turks, non-Turkish labor migrants, Eastern European migrants, and Ethnic Germans. Turks and other labor migrants were recruited as low-skilled and temporary workers ("guest workers"), mostly during the 1960s. After recruitment ceased in 1973 many went back, but a substantial proportion stayed and brought their families to the country. Family and marriage migration from Turkey remained an important source of ethnic replenishment of the Turkish population in Germany up to the 1990s. The origin countries of the other labor migrants, most importantly Spain, Italy, and Greece, soon became immigration countries themselves. The integration of these groups into Germany has progressed faster than that of the Turks, although Italian children are still shown to face substantial challenges in the educational system (Müller and Kogan 2010, p. $257 \mathrm{ff}$.). Turks are not only a larger and more institutionally complete group, but social distances between Turks and natives are much larger than for other, nonMuslim, immigrant groups in Germany. Related to the fact that they are mostly Muslims, that many Turkish women wear a headscarf, and that Turkish names are rather distinct (Gerhards and Hans 2009), natives also perceive them as culturally more distant ${ }^{4}$ than non-Turkish migrants. According to survey data, $56 \%$ of Turks living in Germany think that they can be identified based on their appearance, compared with $24 \%$ of EU migrants and 12\% of Ethnic Germans (SVR-Forschungsbereich 2018, p. 15). In other words, they are visibly more distinct and face salient and "bright" ethnic boundaries (Alba 2005), while this is much less the case for non-Turkish labor migrants such as Italians, Greeks, or Spaniards. Eastern Europeans have come to Germany mostly as internal EU migrants after the EU enlargement. As such, they enjoy far-reaching rights to live and work in Germany. Ethnic Germans returned from Russia to Germany after the fall of the Iron Curtain with high aspirations to

\footnotetext{
${ }^{3}$ Being adequately employed is defined as follows: people with tertiary or higher qualifications are adequately employed if they have an occupational position assigned to ISCO occupational coding 1-3 on the first level scheme. People with lower secondary education up to post-secondary nontertiary education are adequately employed if they have an occupational position assigned to ISCO occupational coding $1-8$ on the first level scheme (the "normative" approach, which uses an a priori presumed correspondence between education and occupations; Quintini 2011, p. 13). When studying adequate employment, the analyzed population is limited to individuals who have been employed at least once during the observed period because we do not have any information on adequate employment for other respondents.

${ }^{4}$ According to data from the German ALLBUS, a biennial population survey conducted in Germany since the 1980s (https://www.gesis.org/en/allbus/allbus-home/general-information/), only about $21 \%$ of German citizens would willingly approve of a Turkish neighbor. These numbers are higher for Italians (70\%) or Ethnic Germans (50\%). Only about $25 \%$ of German respondents think that Turks are culturally similar to Germans, whereas the corresponding numbers for Italians and Ethnic Germans are about 54 and 36\% (reported to be the two most favorable categories on a seven-point scale, German citizens only, ALLBUS data from 2016, own calculations).
} 
live as "Germans among Germans," but are nevertheless often perceived and treated as "Russians" by native Germans.

All of the origin groups include foreign citizens and naturalized migrants. For Ethnic Germans and Eastern Europeans, the few cases that belong to the second generation are included in the respective origin group. We are able to differentiate between first- and second-generation immigrants for those groups that include enough individuals of both groups, namely Turkish and non-Turkish labor migrants and their generation of children born in Germany. Although we expect the mechanisms linking integration and PD spelled out above to hold for both native and foreign-born individuals, generational differences may already tell us something about exposure versus attribution. Exposure should be lower for second-generation migrants from less identifiable origin groups but remain at similar levels (but not increase) for more visible groups. Migrants' awareness of unequal treatment and their aspirations to equal treatment should, however, be higher among those individuals who were born in the host society.

\subsection{Analytic Strategy: Studying the Link Between Integration and PD in a Longitudinal and Group-Comparative Perspective}

We start our analyses by assessing how often respondents from the various origin groups report experiences of discrimination and how stable they are on the individual level. In a second step, we analyze how migrants' level of integration in different domains (acculturation, social integration, identification, and structural integration) affects PD. All the analyses contain group-specific estimates for the relationships between the key variables. Furthermore, we include the psychological characteristics available in the SOEP in all our models (affective wellbeing, locus of control, big five, tendency to forgive, belief that others are fair, belief that others are helpful). We also control for demographic characteristics such as age and sex in all models.

Methodologically, we use hybrid models for logistic panel regression, implemented in a multi-level framework. Hybrid models are "an approach that combines some of the virtues of fixed effects and random effects models" (Allison 2009, p. 23). This method enables us to analyze differences between subgroups (e.g., Turks and other labor migrants) in addition to the effects of time-varying variables (most importantly the ongoing integration processes). In detail, the time-varying independent variables are included as person-specific means (between-person component) and as deviations from person-specific means (within-person component). For a single time-varying attribute $\mathrm{x}$, the basic structure of the model looks as follows:

$$
Y_{i t}=\beta_{0}+\beta_{1}\left(\chi_{i t}-\bar{\chi}_{i}\right)+\beta_{2} \bar{\chi}_{i}+u_{i}+e_{i t}
$$

Accordingly, two coefficients are recorded for the time-varying variables ("M" refers to person-specific means, "D" refers to deviation from those means) in the tables with the regression results. "D" coefficients are equivalent to fixed effects coefficients and can hence be interpreted as being closer to "causal" effects (particularly because the independent variables are lagged) than "M" coefficients, which can be taken as predispositions. To give an example: a positive M coefficient 


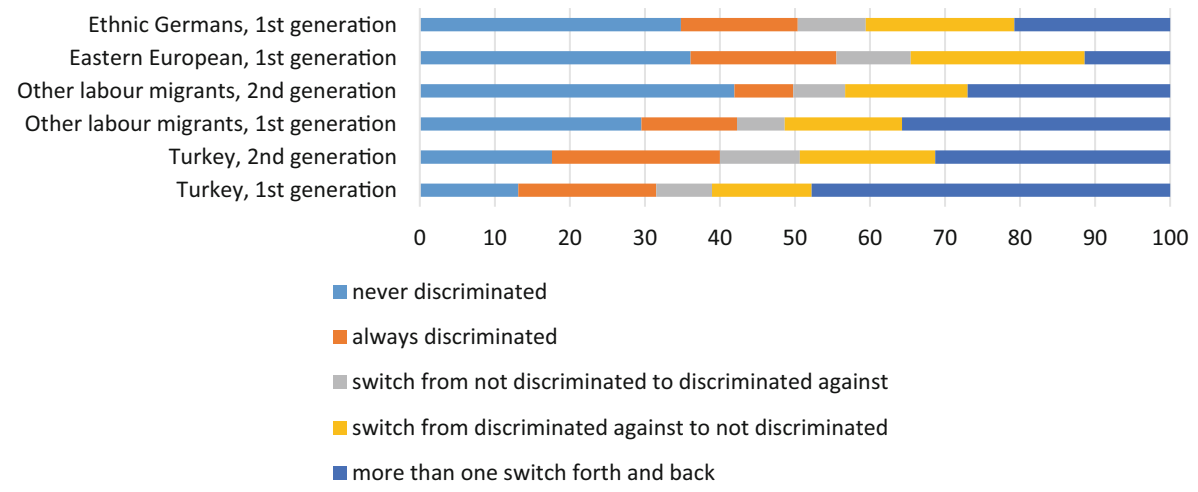

Fig. 1 Group differences and intrapersonal stability in reports of experiences of discrimination among participants in the German Socio-Economic Panel Study. (Only respondents who have answered the question on perceived discrimination at least three times)

for identification with Germany signifies that respondents who tend to identify more strongly with Germany also tend to perceive more discrimination. A higher D coefficient of identification with Germany indicates that respondents are more likely to perceive discrimination after their identification with Germany has increased. All of the time-variant independent variables were lagged for one year in order to model how previous integration progress influences current PD.

If relevant information is missing for a certain survey year, we have replaced it with information available from the most recent year. We use dummy variables for most variables. We control for refusals through missing dummies and also include the respondents' proportion of missing values as a control variable. Table A2 in the Online Appendix gives an overview of the distribution of variables by group and case numbers.

\section{Findings}

Figure 1 displays the percentages of immigrants from different groups who report having experienced disadvantages over the last two years and also provides an insight into the stability of PD over time on an individual basis. We restricted these analyses to respondents who had participated in the SOEP for at least three years. These respondents are grouped into five categories: those who had never reported discrimination; those who had reported discrimination each time they were asked; those who had initially reported discrimination, but in the following years reported no discrimination; those who initially did not report discrimination, but in the following years did report discrimination; and those who had more than one switch from saying that they were discriminated against to saying that they were not discriminated against. Between 12\% (first-generation Turks) and $41 \%$ (second-generation other labor migrants) never report being discriminated against and between $22 \%$ (second-generation Turks) and 7\% (second-generation other labor 
migrants) report experiences of discrimination in every survey wave in which they were asked about it.

The share of those who switch back and forth between reporting and not reporting experiences of discrimination is, however, also substantial. This pattern suggests that there might be some stable interpersonal differences with regard to how much discrimination is perceived, but it excludes the possibility that PD is a more or less stable attitude, only reflecting stable psychological characteristics such as locus of control or trust in other people. We see a different pattern of generational change for Turkish and non-Turkish labor migrants: the latter group feels overall that they are less discriminated against than Turks. In addition, fewer second- than first-generation migrants from Greece, Italy, Spain, etc., report experiences of discrimination every time they were asked and a growing share say that they have never been discriminated against. This is the pattern that one would expect based on assimilation theory. For Turks, both perceptions become more prevalent across generations, i.e., among Turks born in Germany, a larger proportion reports discrimination in each survey year, but the share of those who never report discrimination also grows. As it is unlikely that Turks born in Germany experience more discrimination than the "more visible" firstgeneration Turks (for empirical evidence on this see Zschirnt and Ruedin 2016), this could be a first hint that the link between integration and PD is more complex than one would expect based on the assumption that integration reduces exposure to PD.

\subsection{Who Feels Discriminated Against and How Does This Relate to Integration?}

Table 2 presents the marginal changes in the predicted probabilities (marginal effect at the mean) calculated from logistic hybrid panel regression models with PD as the dependent variable (for underlying full regression models, see Table B1 in the Online Appendix). We first estimate a model for all groups with education and control variables in search of evidence for the "integration paradox" in SOEP data (column 1). We find none, instead observing that those with higher levels of education do not perceive more discrimination than those without. All groups feel substantially less discriminated against than Turkish immigrants. This effect is weakest for secondgeneration Turks and strongest for second-generation labor migrants. In a following step, we insert indicators for migrants' social, identificational, and labor market integration, and for their acculturation. Three results stand out.

First of all, those who have German friends, are adequately employed, identify with Germany, and speak German feel less discriminated against overall. After taking these integration indicators into account, education is positively related to $\mathrm{PD}$ - as predicted by the "integration paradox." Second, increasing integration in any of these domains is not followed by decreasing PD, which means that nothing points toward a causal relationship between integration and PD. Third, psychological characteristics affect PD as well. As expected, an external locus of control (and low affective well-being) are associated with more PD, whereas those who believe that most people try to treat others fairly perceive less discrimination. Smaller negative effects can be found for agreeableness and conscientiousness. The former finding can be read as evidence that those who have the general feeling that their fate 
Table 2 Hybrid models of the relationship between different dimensions of integration and perceived discrimination (marginal change of predicted probabilities for person-specific means $[M]$ and deviations $[D]$ )

\begin{tabular}{|c|c|c|c|c|}
\hline & $\mathrm{D}$ & M & $\mathrm{D}$ & M \\
\hline Turkey, second generation & - & $\begin{array}{l}-0.111 * * * \\
(0.024)\end{array}$ & - & $\begin{array}{l}-0.012 \\
(0.025)\end{array}$ \\
\hline Other labor migrants, first generation & - & $\begin{array}{l}-0.148 * * * \\
(0.017)\end{array}$ & - & $\begin{array}{l}-0.124 * * * \\
(0.017)\end{array}$ \\
\hline $\begin{array}{l}\text { Other labor migrants, second genera- } \\
\text { tion }\end{array}$ & - & $\begin{array}{l}-0.283 * * * \\
(0.019)\end{array}$ & - & $\begin{array}{l}-0.169 * * * \\
(0.021)\end{array}$ \\
\hline Eastern Europeans, first generation & - & $\begin{array}{l}-0.143 * * * \\
(0.024)\end{array}$ & - & $\begin{array}{l}-0.026 \\
(0.025)\end{array}$ \\
\hline Ethnic Germans, first generation & - & $\begin{array}{l}-0.181 * * * \\
(0.017)\end{array}$ & - & $\begin{array}{l}0.0010 \\
(0.021)\end{array}$ \\
\hline Good German language skills & - & - & $\begin{array}{l}0.002 \\
(0.010)\end{array}$ & $\begin{array}{l}-0.048 * * \\
(0.019)\end{array}$ \\
\hline Share of German friends & - & - & $\begin{array}{l}-0.013 \\
(0.011)\end{array}$ & $\begin{array}{l}-0.063^{* * *} \\
(0.019)\end{array}$ \\
\hline Identification with Germany & - & - & $\begin{array}{l}-0.001 \\
(0.010)\end{array}$ & $\begin{array}{l}-0.163^{* * *} \\
(0.018)\end{array}$ \\
\hline More than basic education & $\begin{array}{l}0.011 \\
(0.016)\end{array}$ & $\begin{array}{l}-0.016 \\
(0.014)\end{array}$ & $\begin{array}{l}0.017 \\
(0.017)\end{array}$ & $\begin{array}{l}0.028 * \\
(0.014)\end{array}$ \\
\hline In employment & - & - & $\begin{array}{l}-0.008 \\
(0.013)\end{array}$ & $\begin{array}{l}0.082 * * \\
(0.026)\end{array}$ \\
\hline In adequate employment & - & - & $\begin{array}{l}-0.001 \\
(0.013)\end{array}$ & $\begin{array}{l}-0.080 * * \\
(0.026)\end{array}$ \\
\hline Low affective well-being & - & - & $\begin{array}{l}0.020 * \\
(0.008)\end{array}$ & $\begin{array}{l}0.070 * * * \\
(0.012)\end{array}$ \\
\hline External locus of control & - & - & - & $\begin{array}{l}0.032 * * * \\
(0.006)\end{array}$ \\
\hline Big 5: openness & - & - & - & $\begin{array}{l}0.001 \\
(0.006)\end{array}$ \\
\hline Big 5: conscientiousness & - & - & - & $\begin{array}{l}-0.014 * \\
(0.007)\end{array}$ \\
\hline Big 5: extraversion & - & - & - & $\begin{array}{c}-0.010 \\
(0.006)\end{array}$ \\
\hline Big 5: agreeableness & - & - & - & $\begin{array}{l}-0.017 * * \\
(0.007)\end{array}$ \\
\hline Big 5: neuroticism & - & - & - & $\begin{array}{l}0.010 \\
(0.005)\end{array}$ \\
\hline Tendency to forgive & - & - & - & $\begin{array}{l}-0.009 \\
(0.005)\end{array}$ \\
\hline Most people treat others fairly & - & - & - & $\begin{array}{l}-0.044^{* * * *} \\
(0.013)\end{array}$ \\
\hline Most people try to be helpful & - & - & - & $\begin{array}{c}-0.010 \\
(0.014)\end{array}$ \\
\hline$N$ years in person & - & 28,254 & - & 28,254 \\
\hline$N$ persons & - & 4,442 & - & 4,442 \\
\hline
\end{tabular}

$* p \leq 0.05, * * p \leq 0.01, * * * p \leq 0.001$ 
depends on external circumstances and not so much on themselves are more likely to interpret failure externally, in this case by referring to discrimination.

We have argued above that the available empirical evidence and theoretical reasoning suggest that the link between integration and PD is to some extent group specific. As a reminder, Flores (2015) argues that immigrant groups that are visibly different from the majority population still feel discriminated against at high levels of acculturation. Although he only looks into the effect of language skills, SOEP data enable us to assess group-specific effects between all integration dimensions and PD (see Table 3, for underlying regression models see Table B2 in the Online Appendix).

The results of this exercise are less straightforward, but there is an interesting pattern that is in line with Flores' (2015) argument: high or increasing levels of integration (German friends, language skills and identification) are overall unrelated or negatively related to $\mathrm{PD}$, even though many coefficients are no longer statistically significant when separate groups are considered. For second-generation Turks, in contrast, we see a different pattern: German-born Turks report more rather than less discrimination as their language skills improve (see positive D effects). We see a similar, though less straightforward, finding for a rising level of identification with Germany (see positive D effects); however, those individuals with higher levels of identification report less PD (see negative M effect). Just as summarized in Table 1, identification is related to PD in a complex way. Although we cannot disentangle the different mechanisms possibly linking increasing levels if identification with the host country and PD, our finding is in line with the mechanisms outlined in the literature: Generally, migrants who strongly identify with Germany are less likely to interpret negative incidents through the "lens of discrimination," but in the short run, their aspirations for equal treatment change once their identification increases and they feel more discriminated against.

Well-educated second-generation Turks also report more discrimination than those with lower levels of education (another effect we do not see when we calculate the group-specific effects of education with only control variables included in the model, according to analyses not shown here). Overall, there is-limited-evidence of the "integration paradox" that we find only for German-born Turks and only once we control for their identificational integration. This group has higher levels of education than their parents and also identifies more strongly with Germany. As those who identify as German feel less discriminated against overall (a finding that we discuss in greater detail below), the heightened PD of educated Turks is only revealed once we take this into account.

\section{Discussion and Conclusion}

The aim of this article was to analyze the link between different dimensions of integration and PD for different origin groups based on longitudinal data. We argued that this endeavor provides additional insight into what PD actually captures, exposure or attributional processes, and why PD seems to be higher among more integrated individuals, a phenomenon called the "integration paradox." This is because inte- 


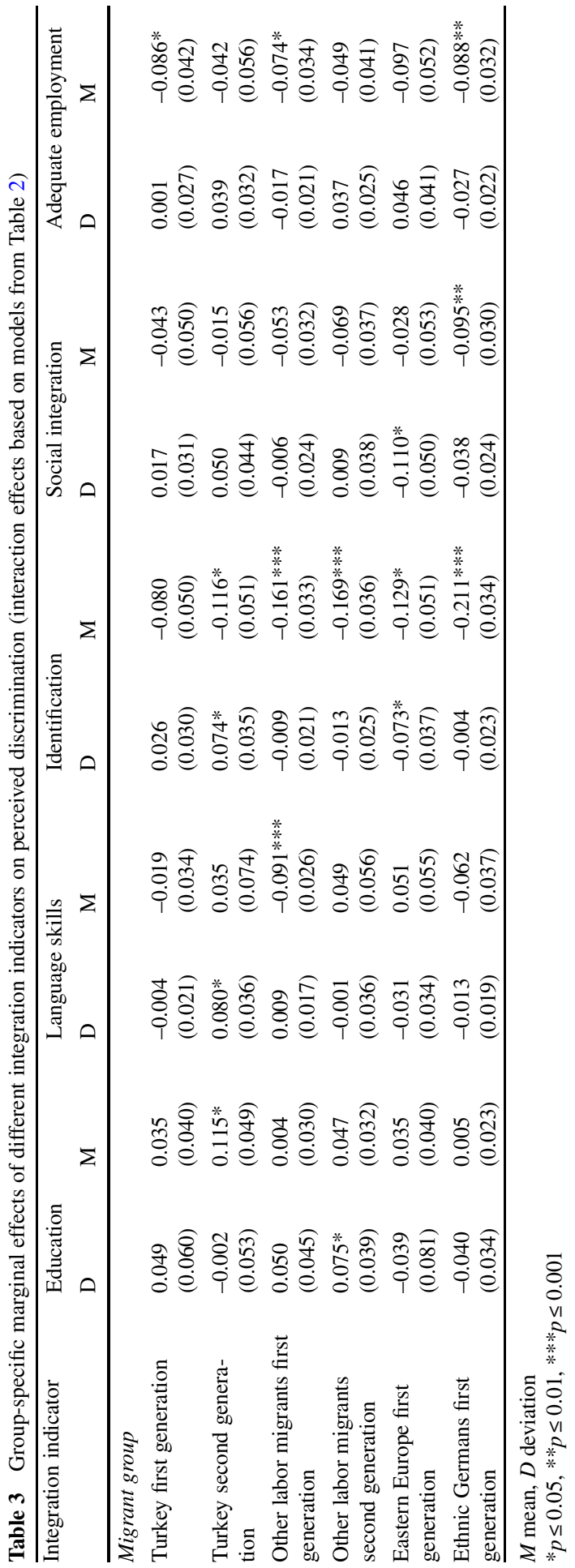


gration in some domains affects mostly an individual's exposure to discrimination, whereas integration in other domains leaves exposure rather unaffected, but changes the attributional processes behind PD. Based on this logic, previous studies have started to open the black box behind PD, but most have focused on specific dimensions of integration, have looked at specific groups of immigrants, or have been based on cross-sectional data.

Our exploration of the relationship between integration and PD has revealed that, in line with assimilation theory, individuals who identify more strongly with Germany, who speak German, who have German friends and who are adequately employed report less discrimination overall. In this respect, we found only limited support for the existence of an "integration paradox." However, group-specific analyses have shown that German-born Turks feel more rather than less discriminated against as their language skills and their identification with Germany increase. But even in this group, the correlation between their identification with Germany and $\mathrm{PD}$ is negative, i.e., individuals who identify more strongly with Germany feel discriminated against less often. Once we control for levels of integration, more educated German-born Turks report experiences of discrimination more often than less educated individuals.

Overall, this complex empirical picture suggests that attributional processes rather than actual exposure to discrimination might explain why, for some groups, rising levels of integration are accompanied by more perceived discrimination. Although it is impossible to fully disentangle the two mechanisms empirically using survey data on PD, we have found indirect evidence for this. We have argued in the theoretical section of this paper that two findings would support the idea that more exposure drives the positive relationship between integration and PD: (1) if PD is higher among more socially integrated individuals (because they spent more time with potential discriminators) and (2) if more educated individuals report higher levels of PD (because members of the majority population feel more threatened by them). Our results show little evidence for either mechanism. Depending on the group under consideration, migrants' social integration is unrelated or negatively related to PD. And although we find that education is positively related to PD for secondgeneration Turks, something in line with the idea that these migrants are perceived as a greater threat by natives, another finding is strongly at odds with it: we do not find such a positive link between education and PD for any other origin group but Turks. It is highly unlikely that natives feel threatened only by educated Turks - who, after all, have lower levels of education overall than other groups under consideration here, e.g., migrants from Eastern Europe.

Our findings rather lend support to the argument that rising aspirations for equal treatment and a greater sensitivity to unequal treatment are the crucial mechanisms that link integration and perceptions of discrimination. First, there is little reason to assume that German-born Turks experience more discrimination after their German language skills improve and after their-invisible-identification with Germany increases. But, given the salient and stable ethnic boundaries they face, it seems very plausible that they increasingly attribute negative experiences to discrimination once they have become so similar to members of the majority population that any form of unequal treatment is obviously unjustified. 
Second, PD correlates with psychological factors such as an external locus of control and the "big five." It is again unlikely that, for example, individuals with an external locus of control are more discriminated against. Instead, this finding supports the argument that attributional processes partly account for interpersonal variance in PD, even though it is theoretically possible that individuals with certain characteristics self-select into discriminatory situations.

But why is the positive link between integration and PD limited, from all the groups included in our analysis, to only German-born Turks? Our descriptive results (Fig. 1) showed a remarkable finding: German-born Turks report as much discrimination as first-generation Turkish immigrants, a finding we do not see for the children of non-Turkish labor migrants. Flores (2015) argues that discrimination does not decline to the same degree as for groups that can easily melt into the mainstream, in our case the children of Italian, Spanish, or Greek labor migrants. At the same time, PD is a cognitive strategy that helps individuals to come to grips with an unpleasant encounter or a negative experience. This strategy is more readily available to groups that have "good reasons" to assume that such experiences are a manifestation of widespread ethnic or racial discrimination (Major and O'Brien 2005, p. 400). The members of groups facing salient ethnic boundaries should thus attribute negative encounters more readily to discrimination (Branscombe et al. 1999, p. 136; Phinney et al. 1998, p. 938), especially when alternative explanations, e.g., a lack of language skills, are not relevant. Note that the argument that discrimination does not disappear for some groups and is revealed by an increasing awareness and sensitivity is a different story than to argue that Turks experience more discrimination as their integration proceeds because they have more contacts with potential discriminators who may also feel increasingly threatened by them.

Our study has not been aimed at testing various existing studies against each other; rather, we have used previous research in order to identify the different theoretical mechanisms that possibly link integration and PD. Previous studies have been based on different data sets, have looked at different groups and contexts and have used different indicators for exposure and attributional processes. None of these studies has systematically taken into account any indicators for migrants' identification with the host country, which, according to our analysis, play an important part in understanding PD, and most have been based on cross-sectional data. Although our results cannot directly be compared with previous findings, evidence for an "integration paradox" is more limited in SOEP data ${ }^{5}$, especially compared with findings from the Netherlands. Nevertheless, our results do line up with the findings from previous studies in several respects. Most importantly, ethnic visibility seems to play an important role in understanding PD (Tuppat and Gerhards 2021) and as a consequence, the link between integration and PD is to some extent group specific (Flores 2015; Steinmann 2019). Our results also point toward the importance of unfulfilled status aspirations (in our case: adequate employment is accompanied

\footnotetext{
5 Tuppat and Gerhards (2021) present evidence for the integration paradox using SOEP data in full models with control variables (e.g., language skills). Their findings are thus not at odds with ours, which suggest that the integration paradox might only show after controls for other indicators of integration are inserted into the models (see Table 2).
} 
by lower PD; see also Schaeffer 2019; Steinmann 2019). We did not, however, find evidence that being in contexts with many members of the majority population leads to heightened levels of PD.

Our research faced several methodological challenges. The indicators for both integration and PD in the SOEP data are limited. New surveys tailored to immigrants could try to capture the core dimensions of integration, such as exposure to discrimination, in a more fine-grained way. More importantly, although our analysis based on German panel data is closer to a causal analysis than many of the available studies, our method cannot fully grapple with problems of reverse causality (for a discussion see Leszczensky and Wolbring 2019). After all, many of our concepts are closely interlinked in complex ways. All the same, given the structure of our data (such as many measurement points over time, large case numbers that allow for group-specific analyses and thus for the inclusion of time-invariant variables), the use of fixed-effects hybrid panel models was a suitable method for investigating our research question.

Future empirical research should seek to further disentangle the exposure to discrimination and the attribution of negative experiences to discrimination, e.g., by holding exposure to discrimination constant in a (field) experimental setting. Another limitation of our data that future surveys could tackle is the lack of longitudinal information on psychological characteristics. Although it seems unlikely that different "personality types" are more exposed to discrimination, some studies suggest that at least some psychological characteristics may also reflect experiences of discrimination (Sutin et al. 2016).

We want to close with a note on the societal implications of our research. The argument that exposure plays a limited role in explaining the "integration paradox" does not imply that perceived discrimination is detached from reality. Compared with contexts such as the USA, where many immigrants are confronted with the legacy of pervasive racism, the levels of discrimination are moderate in Germany and discrimination is often subtle. This is not only what audit studies tell us (Quillian et al. 2019); most SOEP respondents who report any experiences of discrimination say that these happen "seldom." In such a context, the negative experiences that could possibly be related to the ethnic backgrounds of those involved are surrounded by ambiguity and leave room for interpretation. We want to emphasize that the concept of "perceived discrimination" is more complex than often assumed, but another implication of our finding should not be ignored: although each incident of PD may not be a correct account of reality, it is a reality that many immigrants and their children have to live with the expectation of experiencing discriminatory incidents at any time.

Supplementary Information The online version of this article (https://doi.org/10.1007/s11577-02100738-y) contains supplementary material, which is available to authorized users.

Acknowledgements We received many helpful comments on previous versions of this paper. Special thanks go to Jürgen Gerhards, Lars Leszczensky, Karen Phalet, Merlin Schaeffer, and Thomas Soehl.

Funding Open Access funding enabled and organized by Projekt DEAL. 
Open Access This article is licensed under a Creative Commons Attribution 4.0 International License, which permits use, sharing, adaptation, distribution and reproduction in any medium or format, as long as you give appropriate credit to the original author(s) and the source, provide a link to the Creative Commons licence, and indicate if changes were made. The images or other third party material in this article are included in the article's Creative Commons licence, unless indicated otherwise in a credit line to the material. If material is not included in the article's Creative Commons licence and your intended use is not permitted by statutory regulation or exceeds the permitted use, you will need to obtain permission directly from the copyright holder. To view a copy of this licence, visit http://creativecommons.org/licenses/by/4. $0 /$.

\section{References}

Ajzen, Icek. 2002. Perceived Behavioral Control, Self-Efficacy, Locus of Control, and the Theory of Planned Behavior. Journal of Applied Social Psychology 32(4):665-683.

Alba, Richard. 2005. Bright vs. blurred boundaries. Second generation assimilation and exclusion in France, Germany, and the United States. Ethnic and Racial Studies 28(1):20-49.

Alba, Richard, and Victor Nee. 1997. Rethinking Assimilation Theory for a New Era of Immigration. The International Migration Review 31(4): 826-874.

Allison, Paul D. 2009. Fixed Effects Regression Models. Thousand Oaks, CA: Sage Publications.

Berkel, Cady, George P. Knight, Katharina H. Zeiders, Jenn-Yun Tein, Mark W. Roosa, Nancy Gonzales and Delia Saenz. 2010. Discrimination and adjustment for mexican american adolescents. Journal of Research on Adolescence 20(4):893-915.

Branscombe, Nyla R., Michael T. Schmitt and Richard D. Harvey. 1999. Perceiving Pervasive Discrimination Among African Americans. Implications for Group Identification and Well-Being. Journal of Personality and Social Psychology 77(1):135-149.

Brücker, Herbert, Martin Kroh, Simone Bartsch, Jan Goebel, Simon Kühne, Elisabeth Liebau, Parvati Trübswetter, Ingrid Tucci and Jürgen Schupp. 2014. The new IAB-SOEP Migration Sample. An introduction into the methodology and the contents. SOEP Survey Papers 216: Series C. Berlin: DIW/SOEP.

Coenders, Marcel, and Peer Scheepers. 2003. The Effect of Education on Nationalism and Ethnic Exclusionism. An International Comparison. Political Psychology 24(2), Special Issue: National Identity in Europe (Jun., 2003):313-343.

Crocker, Jennifer, and Brenda Major. 1989. Social Stigma and Self-Esteem. The Self-Protective Properties of Stigma. Psychological Review 96(4):608-630.

Diehl, Claudia, Marion Fischer-Neumann and Peter Muhlau. 2016. Between ethnic options and ethnic boundaries. Recent Polish and Turkish migrants' identification with Germany. In Starting out. New migrants' socio-cultural integration trajectories in four European destinations. Ethnicities, Special Issue 16 (2), eds. Claudia Diehl, Marcel Lubbers, Peter Muhlau and Lucinda Platt, 236-260. Norwich: Sage.

van Doorn, Majka, Peer Scheepers, and Jaco Dagevos. 2013. Explaining the Integration Paradox Among Small Immigrant Groups in the Netherlands. Journal of International Migration and Integration 14(2):381-400.

Fischer-Neumann, Marion. 2014. Migrants' Ethnic Identification and Political Involvement in the Face of Discrimination. A Longitudinal Study of the German Case. Journal of Ethnic and Migration Studies 40(3):339-362.

Fleischmann, Fenella, and Karen Phalet. 2012. Integration and religiosity among the Turkish second generation in Europe. A comparative analysis across four capital cities. Ethnic and Racial Studies 35(2):320-341.

Fleischmann, Fenella, Karen Phalet and Olivier Klein. 2011. Religious identification and politicization in the face of discrimination. Support for political Islam and political action among the Turkish and Moroccan second generation in Europe. British Journal of Social Psychology 50(4):628-648.

Flippen, Chenoa A., and Emilio A. Parrado. 2015. Perceived discrimination among Latino immigrants in new destinations. The case of Durham, North Carolina. Sociological Perspectives 58(4):666-685.

Flores, René D. 2015. The Resurgence of Race in Spain. Perceptions of Discrimination Among Immigrants. Social Forces 94(1):237-269.

Gerhards, Jürgen, and Silke Hans. 2009. From Hasan to Herbert. Name-Giving Patterns of Immigrant Parents between Acculturation and Ethnic Maintenance. American Journal of Sociology 114(4):1102-1028. 
Goebel, Jan, Markus M. Grabka, Stefan Liebig, Martin Kroh, David Richter, Carsten Schröder and Jürgen Schupp. 2019. The German Socio-Economic Panel Study (SOEP). Jahrbücher für Nationalökonomie und Statistik/Journal of Economics and Statistics 239(2):345-360.

Gordon, Milton. 1964. Assimilation in American life. The Role of Race, Religion, and National Origins. New York: Oxford University Press.

Hello, Evelyn, Peer Scheepers and Mérove Gijsberts. 2002. Education and Ethnic Prejudice in Europe. Explanations for cross-national variances in the educational effect on ethnic prejudice. Scandinavian Journal of Educational Research 46(1):5-24.

Horr, Andreas, Christian Hunkler and Clemens Kroneberg. 2018. Ethnic Discrimination in the German Housing Market. Zeitschrift für Soziologie 47(2):134-146.

Jasinskaja-Lahti, Inga, Karmela Liebkind and Erling Spolheim. 2009. To Identify or Not To Identify? National Disidentification as an Alternative Reaction to Perceived Ethnic Discrimination. Applied Psychology 58(1):105-128.

Jugert, Philipp, Sebastian Pink, Fenella Fleischmann, and Lars Leszczensky. 2020. Changes in Turkishand Resettler-origin Adolescents' Acculturation Profiles of Identification: A Three-year Longitudinal Study from Germany. Journal of Youth and Adolescence 49:2476-2494.

Koopmans, Ruud. 2016. Does assimilation work? Sociocultural determinants of labour market participation of European Muslims. Journal of Ethnic and Migration Studies 42(2):197-216.

Leszczensky, Lars, and Tobias Wolbring. 2019. How to Deal With Reverse Causality Using Panel Data? Recommendations for Researchers Based on a Simulation Study. Sociological Methods \& Research. https://doi.org/10.1177/0049124119882473

Liebau, Elisabeth, and Ingrid Tucci. 2015. Migrations- und Integrationsforschung mit dem SOEP von 1984 bis 2012. Erhebung, Indikatoren und Potenziale. SOEP Survey Papers 270: Series C. Berlin: DIW/SOEP.

Major, Brenda, and Laurie O'Brien. 2005. The Social Psychology of Stigma. Annual Review of Psychology 56(1):393-421.

Maliepaard, Mieke, and Richard Alba. 2016. Cultural Integration in the Muslim Second Generation in the Netherlands. The Case of Gender Ideology. International Migration Review 50(1):70-94.

Martinovic, Borja, and Maykel Verkuyten. 2012. Host national and religious identification among Turkish Muslims in Western Europe. The role of ingroup norms, perceived discrimination and value incompatibility. European Journal of Social Psychology 42(7):893-903.

Maxwell, Rahsaan. 2015. Perceived Discrimination across Institutional Fields. Racial Minorities in the United Kingdom. European Sociological Review 31(3):342-353.

McGinnity, Frances, and Merove Gijsberts. 2016. A threat in the air? Perceptions of group discrimination in the first years after migration: Comparing Polish Migrants in Germany, the Netherlands, the UK and Ireland. Ethnicities 16(2)261-289.

Müller, Walter, and Irena Kogan. 2010. Education. In Handbook of European Societies. Transformations in the 21st Century, eds. Stefan Immerfall and Göran Therborn, 217-289. New York: Springer.

National Research Council. 2004. Measuring racial discrimination. Eds. Rebecca M. Blank, Marilyn Dabady and Constance F. Citro, Committee on National Statistics, Division of Bahavioral and Social Sciences and Education. Washington, DC: The National Academies Press.

Pager, Devah. 2007. The Use of Field Experiments for Studies of Employment Discrimination. Contribution, Critiques, and Directions for the Future. Annals of the American Academy of Political and Social Sciences 609(1):104-133.

Pew Research Center, February, 2017. "What It Takes to Truly Be 'One of Us"”

Phinney, Jean S., Tanya Madden and Lorena J. Santos. 1998. Psychological Variables as Predictors of Perceived Ethnic Discrimination Among Minority and Immigrant Adolescents. Journal of Applied Social Psychology 28(11):937-953.

Quillian, Lincoln. 2006. New Approaches to Understanding Racial Prejudice and Discrimination. Annual Review of Sociology 32:299-328.

Quillian, Lincoln, Anthony Heath, Devah Pager, Arnfinn H. Midtbøen, Fanella Fleischmann and Ole Hexel. 2019. Do Some Countries Discriminate More than Others? Evidence from 97 Field Experiments of Racial Discrimination in Hiring. Sociological Science 6:467-496.

Quintini, Glenda. 2011. Over-qualified or under-skilled. A review of existing literature. OECD Social, Employment and Migration Working Papers 121, OECD Publishing. DOI: 10.1787/5kg58j9d7b6den.

Röder, Antje, and Marcel Lubbers. 2016. After migration: Acculturation of attitudes towards homosexuality among Polish immigrants in Germany, Ireland, the Netherlands and the UK. Ethnicities 16(2):261-289. 
Röder, Antje, and Peter Mühlau. 2012. What determines the trust of immigrants in criminal justice institutions in Europe? European Journal of Criminology 9(4):370-387.

Saint Pierre, Francesca Di, Borja Martinovic and Thomas De Vroome. 2015. Return Wishes of Refugees in the Netherlands. The Role of Integration, Host National Identification and Perceived Discrimination. Journal of Ethnic and Migration Studies 41 (11):1836-1857.

Schacht, Diana, Cornelia Kirsten and Ingrid Tucci. 2014. Interethnische Freundschaften in Deutschland. Kölner Zeitschrift für Soziologie und Sozialpsychologie 66:445-458.

Schaeffer, Merlin. 2019. Social Mobility and Perceived Discrimination. Adding an Intergenerational Perspective. European Sociological Review 35:65-80.

Schmaus, Miriam. 2019. Ethnic Differences in Labour Market Outcomes. The Role of Language-Based Discrimination. European Sociological Review 36(1):82-103.

Schmitt, Michael T., and Nyla R. Branscombe. 2002. The Meaning and Consequences of Perceived Discrimination in Disadvantaged and Privileged Social Groups. European Review of Social Psychology 12(1):167-199.

Skrobanek, Jan. 2009. Perceived Discrimination, Ethnic Identity and the (Re-) Ethnicisation of Youth with a Turkish Ethnic Background in Germany. Journal of Ethnic and Migration Studies 35(4):535-554.

Small, Mario L., and Devah Pager. 2020. Sociological Perspectives on Racial Discrimination. Journal of Economic Perspectives 34(2):49-67.

Steinmann, Jan-Philip. 2019. The paradox of integration. Why do higher educated new immigrants perceive more discrimination in Germany? Journal of Ethnic and Migration Studies 45(9):1377-1400.

Sutin, Angelina R., Yannick Stephan and Antonio Terracciano. 2016. Perceived Discrimination and Personality Development in Adulthood. Developmental Psychology 52(1):155-163.

SVR-Forschungsbereich. 2018. „Wo kommen Sie eigentlich ursprünglich her?“. Diskriminierungserfahrungen und phänotypische Differenz in Deutschland. Berlin.

ten Teije, Irene, Marcel Coenders and Maykel Verkuyten. 2013. The Paradox of Integration. Immigrants and Their Attitude Toward the Native Population. Social Psychology 44(4):278-288.

Thijs, Jochem, and Dea Piscoi. 2016. Perceiving discrimination in "real life". Distinguishing negative events from discrimination attributions. Basic and Applied Social Psychology 38(3):166-172.

Tolsma, Jochem, Marcel Lubbers and Mérove Gijsberts. 2012. Education and Cultural Integration among Ethnic Minorities and Natives in the Netherlands. A Test of the Integration Paradox. Journal of Ethnic and Migration Studies 38(5):793-813.

Tuppat, Julia, and Jürgen Gerhards. 2021. Immigrants' First Names and Perceived Discrimination. A Contribution to Understanding the Integration Paradox. European Sociological Review 37(1):121-135.

Verkuyten, Maykel. 2016. The Integration Paradox. Empirical Evidence From the Netherlands. American Behavioral Scientist 60(5-6):583-596.

Verkuyten, Maykel, and Ali Aslan Yildiz. 2007. National (Dis)identification and Ethnic and Religious Identity. A Study Among Turkish-Dutch Muslims. Personality and Social Psychology Bulletin 33(10):1448-1462.

Voas, David, and Fenella Fleischmann. 2012. Islam Moves West. Religious Change in the First and Second Generations. Annual Review of Sociology 38(1):525-545.

de Vroome, Thomas, Maykel Verkuyten and Borja Martinovic. 2014. Host National Identification of Immigrants in the Netherlands. International Migration Review 48(1):76-102.

Wimmer, Andreas. 2008. The Making and Unmaking of Ethnic Boundaries. A Multilevel Process Theory. American Journal of Sociology 113(4):970-1022.

Zschirnt, Eva, and Didier Ruedin. 2016. Ethnic discrimination in hiring decisions. A metaanalysis of correspondence tests 1990-2015. Journal of Ethnic and Migration Studies 42(7):1115-1134.

Claudia Diehl Prof. Dr., University of Konstanz, Cluster of Excellence “The Politics of Inequality”. Fields of research: Migration and integration processes, xenophobia and discrimination. Publications: Starting out: New migrants' socio-cultural integration trajectories in four European destinations. Ethnicities 2016 (ed. with M. Lubbers, L. Platt and P. Mühlau); Ethnische Ungleichheiten im Bildungsverlauf 2016 (with C. Hunkler and C. Kristen); Who Is Afraid of Skilled Migrants From Europe? Swiss Journal of Sociology 2018 (with T. Hinz and K. Auspurg) 
Elisabeth Liebau Dr., DIW Berlin, Survey management of the SOEP. Fields of research: Content-related and survey methodological issues in the area of migration and integration. Publications: The role of socioeconomic, cultural, and structural factors in daycare attendance among refugee children. Journal for Educational Research Online 2021 (with C. Homuth and G. Will); Wie gut funktioniert das OnomastikVerfahren? Ein Test am Beispiel des SOEP-Datensatzes. SOEP paper 976, 2018 (with A. Humpert and K. Schneiderheinze).

Peter Muhlau Dr., Assistant Professor, Trinity College Dublin. Fields of research: Migration, employment, xenophobia. Publications: Discrimination in the rental housing market: a field experiment in Ireland, Journal of Ethnic and Migration Studies 2021 (with E. Gusciute and R. Layte); All Welcome Here? Attitudes towards Muslim Migrants in Europe, International Migration, 2021 (with E. Gusciute and R. Layte); Mobilising social network support for childcare: The case of Polish migrant mothers in Dublin, Social Networks 2018 (with S. Bojarczuk). 